\title{
COMBINATION OF PATCH AND WHEEL LOADS - ANALYTICAL APPROACH TO PLATE BUCKLING
}

\author{
Olga Mijušković* \\ University of Montenegro, Faculty of Civil Engineering, Podgorica, Montenegro \\ Branislav Ćorić \\ University of Belgrade, Faculty of Civil Engineering, Belgrade, Serbia \\ Biljana Ščepanović \\ University of Montenegro, Faculty of Civil Engineering, Podgorica, Montenegro
}

Past studies on the stability of rectangular plates under the influence of variable loads were based on assumptions of simplified stress distributions, which put the question of the accuracy of results thus obtained. The procedure of applying the exact stress functions in the problem of elastic stability of the plate with different boundary conditions under effects of patch and wheel loading is presented in this paper. Mathieu (1890) obtained the exact solution for the plane-strain state for a rectangular element for certain types of variable stresses on the boundaries. Baker at al (1993), following Mathieu's results, analyzed the general problem of a rectangular plate loaded by completely arbitrary distributions of (normal and/or shear) stresses along the edges of the plate. Analytical approach used for determination of the critical load is based on well known Ritz energy technique. The strain energy due to bending of the plate is defined in the traditional way. On the other hand, the exact stress distribution of Mathieu's theory of elasticity is introduced through the potential energy of the plate associated with the work done by external loads. Results for the critical load obtained by presented analytical approach are reaffirmed by numerical finite-element (FE) runs.

Key words: Elastic stability of plates, Exact stress function, Patch and wheel load

\section{INTRODUCTION}

In steel structures, buckling problem of the high steel girders under variable external loads is still very interesting topic. Presently available literature abounds with data regarding this problem, but mostly obtained by numerical or experimental methods. Analytical approach has been avoided mostly because of unknown stress distribution.

In the series of papers based on Mathieu's method from 1890 [02], Pavlović, Baker and Tahan [08] and later Liu [05] and Mijušković [02] developed very precise approach for exact stress function determination for main case of rectangular plate under arbitrary external load. Existence of such solutions created the basis for the analysis of very complex stability problems in real steel structures.

The case of patch and wheel loads can now be analyzed by using different mathematical models which are describing the mentioned problem with different levels of accuracy. Considering models with different levels of complexity, it is possible to compare the results and analyze contribution of individual parameters to the value of the critical load.

In this paper, the first, basic mathematical model is chosen to represent buckling problems of plates under combination of locally distributed compression and system of concentrated forces (Figure 1).

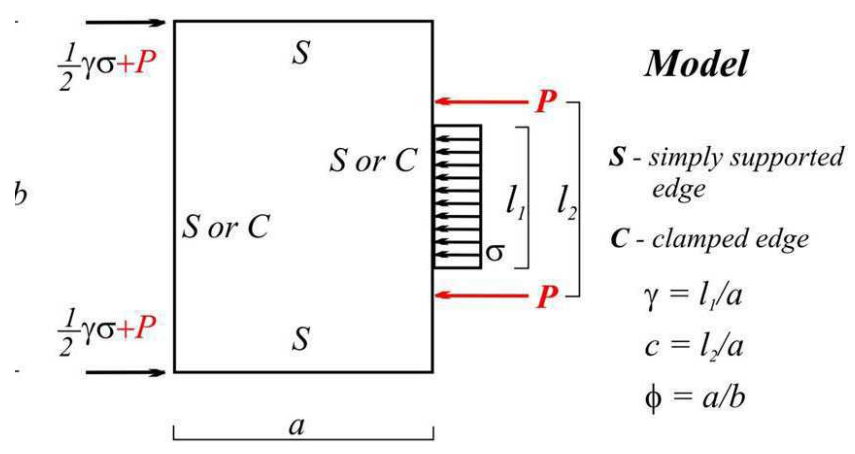

Figure 1: Basic model for patch-loading analysis 
The next step would be raising model to a more complex level through introduction of the shear stresses along vertical stiffeners with task to equilibrate external loads. The final goal would be defining and analyzing model with effects of shear stress at the flange-web junction whose distribution depends on the rigidity of the flange. Comparative analysis of the three models defining stability problem of rectangular plates with different boundary conditions under patch loading, can point to interesting conclusions about the relevance of various parameters and their influence on the value of the critical load.

\section{BASIC OUTLINE}

Analytical approach to stability problems of the plates due to the patch and wheel loading begins with determination of exact stress functions for selected model.

In the series of papers [08-02] it has been already explained that any arbitrary load (normal and/or shear) which acts along the edges of the plate, can be described by the chosen functions (even and/or odd in relation to the coordinate axes), so the total solution is obtained by the adequate combination of eight basic cases (Figure 2).
In the Figure 3 the procedure for obtaining the exact stress distribution for the adopted model is explained by superposition of the adequate DEA and DEB solutions. The possibility to achieve exact stress functions for complex cases of plates under patch loading guarantees accurate analytical approach to critical load determination. So far, in the literature, only in the researches of Pavlović and Liu [01], it is possible to find analytical results for buckling loads, but exclusively for simply supported plates. Up to now, for this load case and the plates with different boundary conditions, there are no precise analytical solutions.

Since the results for stress functions for the DEA and DEB cases can be found in literature [01-04] only Mathieu's basic approach will be presented in this paper.

In his paper [02], Mathieu expressed the known equilibrium equations, without the presence of body forces, in terms of displacements:

$$
\begin{aligned}
& \frac{\partial \sigma_{x}}{\partial x}+\frac{\partial \tau_{x y}}{\partial y}=0 \quad \Delta u=-\frac{1}{\varepsilon} \frac{d v}{d x} \\
& \frac{\partial \tau_{y x}}{\partial x}+\frac{\partial \sigma_{y}}{\partial y}=0 \quad \text { Mathieu } \Rightarrow \Delta v=-\frac{1}{\varepsilon} \frac{d v}{d y}
\end{aligned}
$$

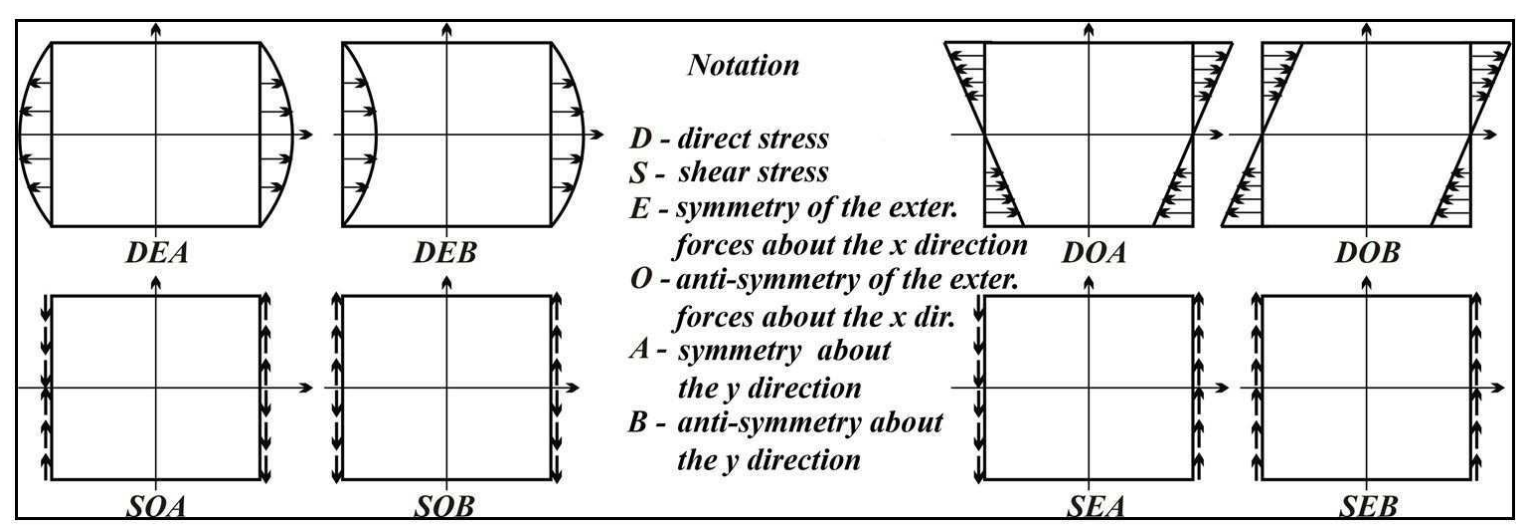

Figure 2: Eight basic load cases

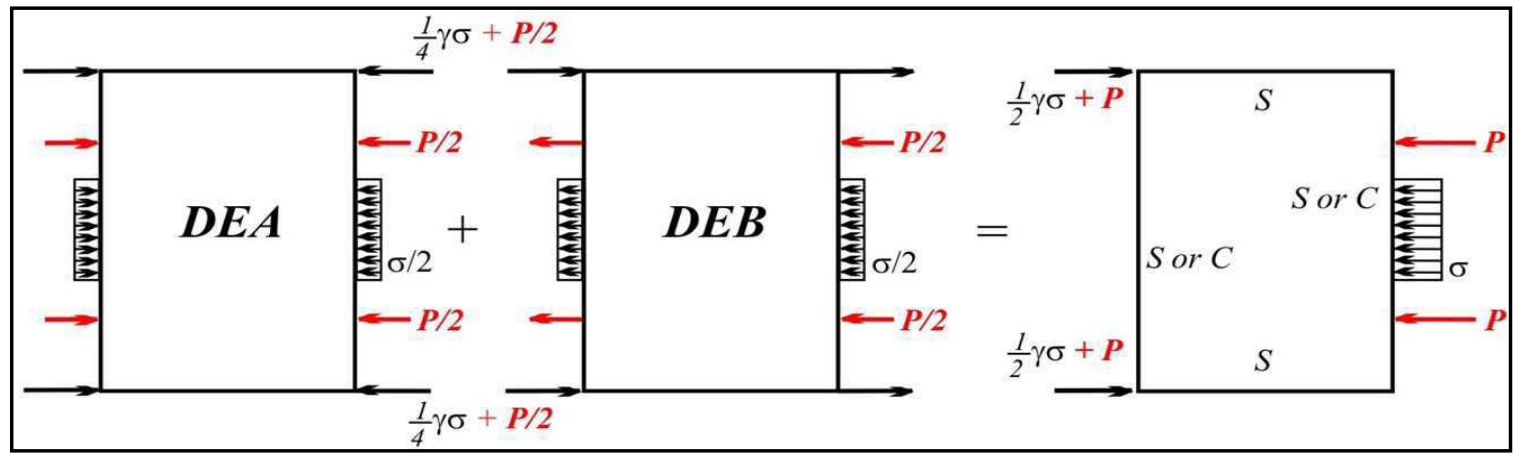

Figure 3: Basic model (DEA and DEB combination) 
where:

\section{$\Delta$ - Laplace's operator}

$\mathrm{u}, \mathrm{v}$ - displacements along the $\mathrm{x} \mathrm{i}$ y directions respectively,

$v=\frac{\partial u}{\partial x}+\frac{\partial v}{\partial y}-$ volumetric dilatation and

$\varepsilon=\mu /(\lambda+\mu)$ - parameter related to Lame's constants

With the quite simple mathematical operations system (Eqs. (1)) can be transformed into the following form:

$\Delta v=0$

Mathieu's approach to the 2D elasticity problem starts with the careful selection of two ordinary Fourier series for $v$ (Eq.(2)) with infinite unknown coefficients, taking into account the symmetry or anti-symmetry of the stresses with respect to the $x$ and $y$ directions.

$v=v_{1}+v_{2}$

The following step presents the introduction of the function $F(F 1+F 2)$, from the conditions that the equation is fulfilled:

$\Delta F=-\frac{1}{\varepsilon} v \Rightarrow \Delta F_{1}=-\frac{1}{\varepsilon} v_{1} \quad i \quad \Delta F_{2}=-\frac{1}{\varepsilon} v_{2}$

Finally, when displacements $u$ i $v$ are determined

$u=\frac{d F}{d x}+\alpha \int v_{1} d x \quad i \quad v=\frac{d F}{d y}+\alpha \int v_{2} d y$

where $\quad \alpha=\frac{(\lambda+2 \mu)}{\mu}$ is constant expressed in terms of Lame's parameters, normal stresses $N_{1}$ and $N_{2}$ are defined along the $x$ i $y$ axes, as well as in-plane shear stress $T_{3}$.

$N_{1}=\lambda v+2 \mu \alpha v_{1}+2 \mu \frac{d^{2} F}{d x^{2}}$

$N_{2}=\lambda v+2 \mu \alpha v_{2}+2 \mu \frac{d^{2} F}{d y^{2}}$

$T_{3}=\mu\left[2 \frac{d^{2} F}{d x d y}+\alpha \int \frac{d v_{1}}{d y} d x+\alpha \int \frac{d v_{2}}{d x} d y\right]$

Analytical procedure for exact stress and displacement function determination is very complex and demanding. So, in order to enable stability analysis of plates under arbitrary external load, with possibility to vary dimensions and boundary conditions, it was absolutely necessary to cre- ate general program (symbolic programming in the Mathematica) with implemented stress solutions for basic load cases (for original and rotate configuration LOAD, LOAD(ROT), Figure 2). Up to now, program contains general solutions for stress and displacement functions for six/twelve basic load cases (four/eight in self-equilibrium $D E A^{(\mathrm{ROT})}, \mathrm{DOA}^{(\mathrm{ROT})}, \mathrm{SOA}^{(\mathrm{ROT})}$ and $\mathrm{SOB}^{(\mathrm{ROT})}$, and two/four that involve rigid-body translation $\mathrm{DEB}^{(\mathrm{ROT})}$ and SEB $\left.{ }^{(\mathrm{ROT})}\right)$.

The concept of computer program enables control of two highly important parameters that affects quality of solutions for stress functions. The first parameter is related to strict check of convergence and value stabilization of unknown coefficients in expressions for stresses while the second parameter determines necessary number of terms included in stress functions. More about mentioned parameters, as well as their influence on final stress value for some basic load cases can be found in literature [07-04].

In order to emphasize the quality of stress solutions, it has been decided to present one highly demanding load type - combination of patch load $(y=0.1)$ and concentrated forces $(c=0.5)$ (example in Table 1). Having in mind existence of girder reactions in form of concentrated forces, causing extreme stress concentration close to point supports, it was absolutely necessary to predefine identical stress contours in both cases - analytical and numerical (ANSYS) solutions in order to enable adequate comparison of their position.

Table 1: Stresses distributions within plate for the specific case of patch and wheel load combination obtained by analytical procedure and by software (ANSYS)

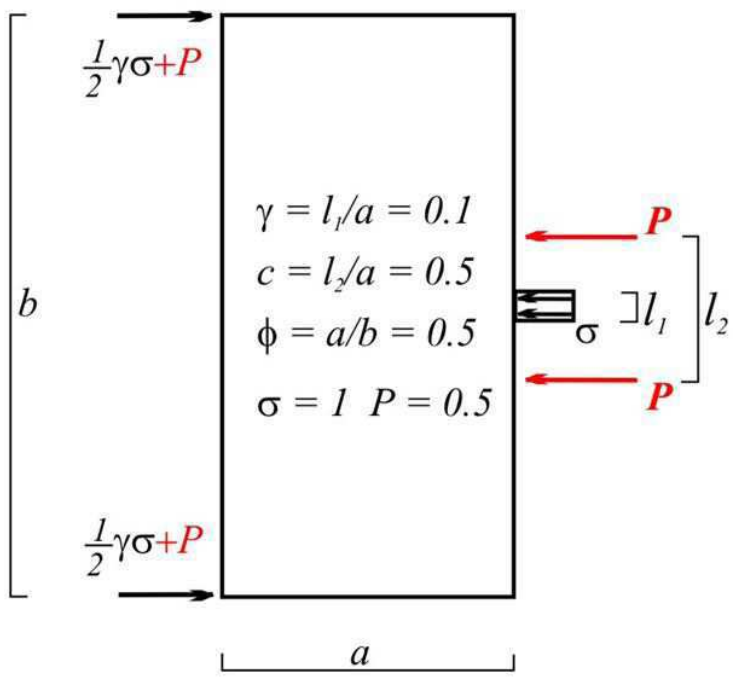

Journal of Applied Engineering Science 14(2016)1, 357 


\section{ANSYS (FEM)}

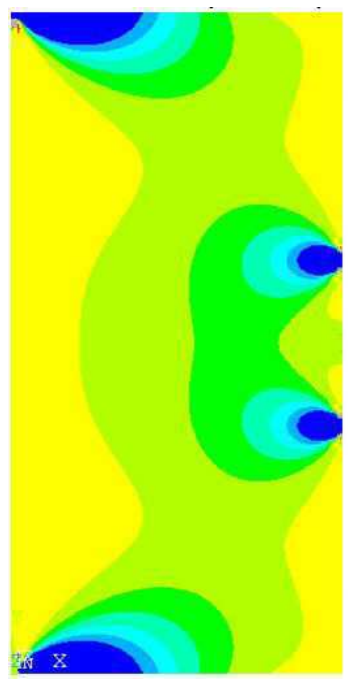

ANSYS (FEM)

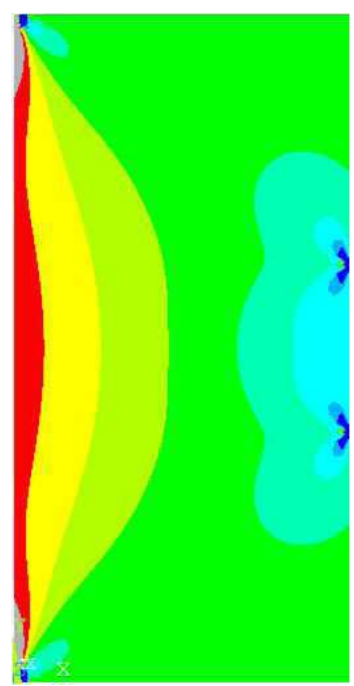

ANSYS (FEM)

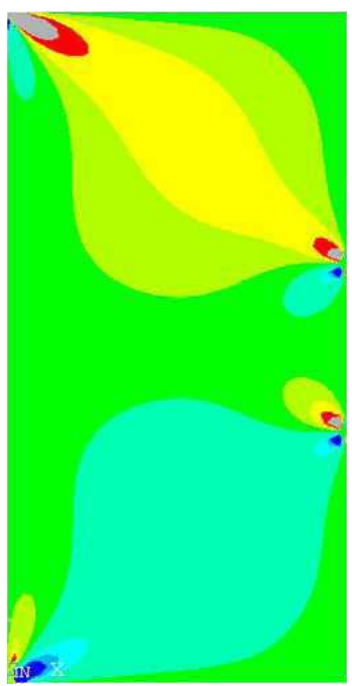

\section{Normal stress $\sigma_{x}$}

Analytical solution

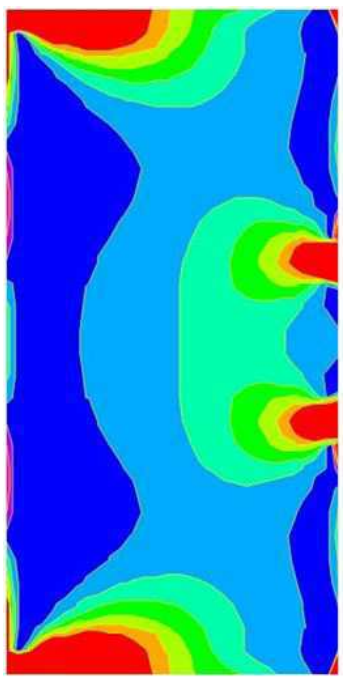

Normal stress $\sigma_{y}$

Analytical solution

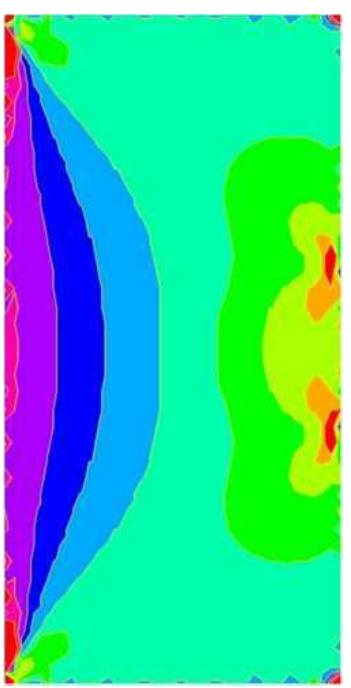

Shear stress $\mathbf{T}_{x y}$ Analytical solution

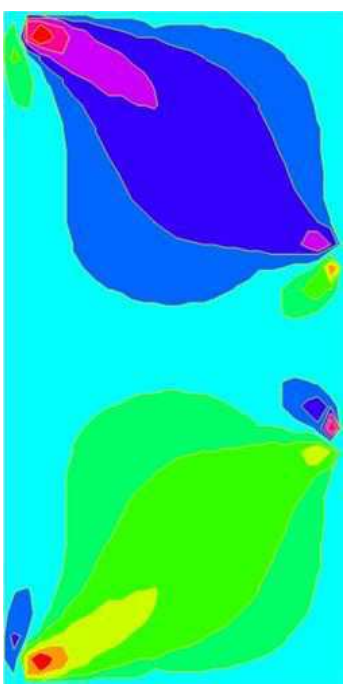

Overlap

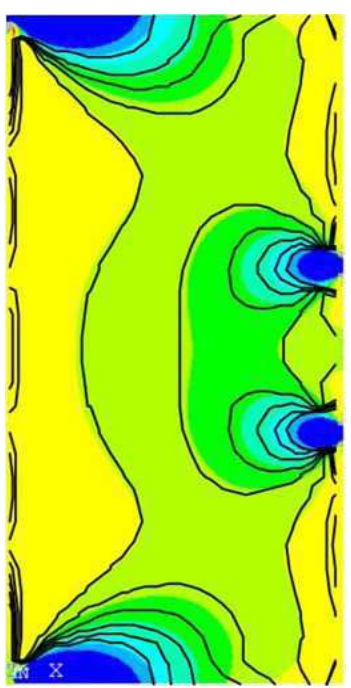

Overlap

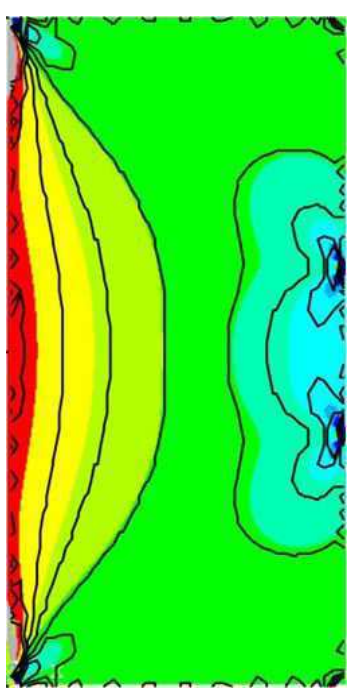

Overlap

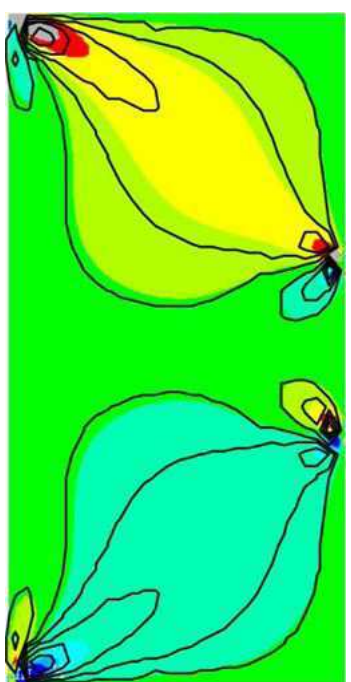


Finally, analysis of diagrams in Table 1, especially in the third column presenting overlap of stress contours, shows that shapes and values of analytical and numerical solutions have high level of match.

\section{ANALYTICAL APPROACH TO PLATE BUCKLING}

The problem of the elastic stability of rectangular plates with different boundary conditions is investigated using the Ritz energy technique. The strain energy due to bending of the plate is defined in the traditional way. On the other hand, the exact stress distribution of Mathieu's theory of elasticity is introduced through the potential energy of the plate associated with the work done by external loads [05-04]. By adopting the exact stresses within a plate under patch and wheel loading and using the double Fourier series to represent any possible buckled profile, the buckling loads can

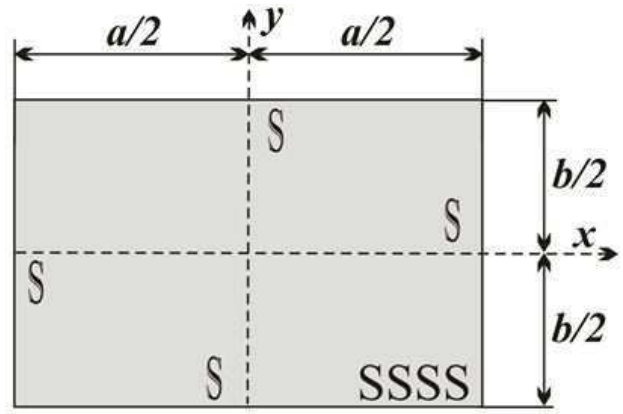

edges $x= \pm a / 2$ simply supported (S) edges $y= \pm b / 2$ simply supported (S)

Figure 4: Simply supported plate SSSS be obtained in a very accurate way. Analytical approach to plate buckling under patch and wheel loading is presented in the examples of the rectangular simply supported plates (SSSS) as well as in plates with two edges simply supported and other two clamped (CSCS). In order to verify the results from analytical method, the finite-element method (ANSYS) is used to produce buckling coefficients for the considered problem. Presently available literature has no records on analytical solutions dealing with the subject.

\section{The adopted deflection series}

In order to guarantee the accuracy, the double Fourier series are used to represent buckled profiles of the two chosen types of plates Eqs. (7) - (8). These series satisfy all boundary conditions, term by term, and, as it has been previously shown, are capable of representing any possible buckled profiles for very wide range of aspect ratios and load cases.

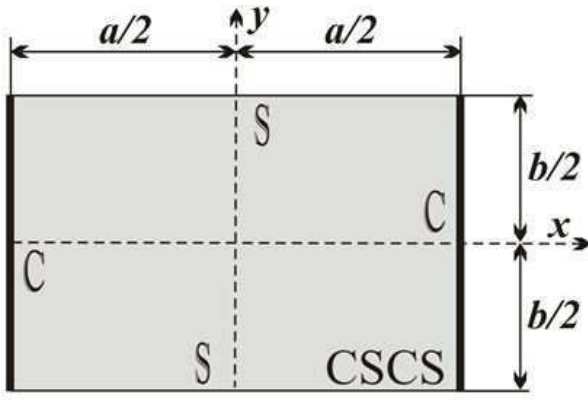

edges $x= \pm a / 2$ clamped $(C)$

edges $\mathrm{y}= \pm \mathrm{b} / 2$ simply supported (S)

Figure 5: Plate with mixed boundary conditions CSCS

$$
\begin{gathered}
w=\sum_{m=1}^{s} \sum_{n=1}^{s} W_{m n} \sin \frac{m \pi}{a}\left(x+\frac{a}{2}\right) \sin \frac{n \pi}{b}\left(y+\frac{b}{2}\right) \\
w=\sum_{m=1}^{s} \sum_{n=1}^{s} W_{m n}\left(\cos \frac{(m-1) \pi}{a}\left(x+\frac{a}{2}\right)-\cos \frac{(m+1) \pi}{a}\left(x+\frac{a}{2}\right)\right) \sin \frac{n \pi}{b}\left(y+\frac{b}{2}\right)
\end{gathered}
$$

Strain energy due to bending and work done by external loads

During the evaluation of the total potential energy of the plate, the first step is defining the strain energy due plate bending in the traditional way.
The part of the potential energy of the plate associated with the work done by external loads is presented by the Eq. (10). In this expression, the stresses within the plate $N_{1}, N_{2}$ and $T_{3}$ are given by Eqs. (6a) - (6c) that represent solutions of the Mathieu's exact approach.

$$
\begin{gathered}
U=\frac{1}{2} D \int_{-a / 2}^{a / 2} \int_{-b / 2}^{b / 2}\left[\left(\frac{\partial^{2} w}{\partial x^{2}}+\frac{\partial^{2} w}{\partial y^{2}}\right)^{2}-2(1-v)\left[\frac{\partial^{2} w}{\partial x^{2}} \frac{\partial^{2} w}{\partial y^{2}}-\left(\frac{\partial^{2} w}{\partial x \partial y}\right)^{2}\right]\right] d x d y \\
V=-\frac{t}{2} \int_{-a / 2}^{a / 2} \int_{-b / 2}^{b / 2}\left[N_{1}\left(\frac{\partial w}{\partial x}\right)^{2}+N_{2}\left(\frac{\partial w}{\partial y}\right)^{2}+2 T_{3} \frac{\partial w}{\partial x} \frac{\partial w}{\partial y}\right] d x d y
\end{gathered}
$$


Introducing the exact stress functions for arbitrary type of external load makes the expression for the work done by external forces Eq. (10) more complex. It presents the basic difference in relation to the previous analyses of the stability of plates which are not simply supported along all edges.

\section{Formulation of eigenvalue problem}

Finally, after the definition of the strain energy of the plate bending $U$, and of the value which responds to the work done by external forces $\mathrm{V}$, the total potential energy of the system can be written in form $\Pi=U+V$. From the minimum potential energy principle, the condition $\Pi=U+V$ is given by

$\frac{\partial \Pi}{\partial W_{m n}}=\frac{\partial U}{\partial W_{m n}}+\frac{\partial V}{\partial W_{m n}}$ which basically represents linear system of $m \bullet n$ homogenous equations per unknown coefficients Wmn. The existence of nontrivial solution, expressed through condition that the determinant of the system is equal to zero, leads to the solution of the classical eigenvalue problem. In its scope, the lowest value has, for us, the only practical importance, which presents the requested critical load.

Accuracy and quality of the second program part, related to the problems of plates stability, will be presented through analyzed case of patch and wheel load (from Table 1). In Table 2, for two types of boundary conditions (SSSS and CSCS), buckling coefficients are defined and appropriate buckling shapes are presented, in order to control the ability of chosen deflection functions to depict all buckling shapes. It may be concluded that critical load, as well as buckling shapes (Table 2) have a perfect match with numerical (ANSYS) solutions.

Table 2: Buckling shapes obtained by analytical procedure and by software (ANSYS) based on the finite element method (FEM)

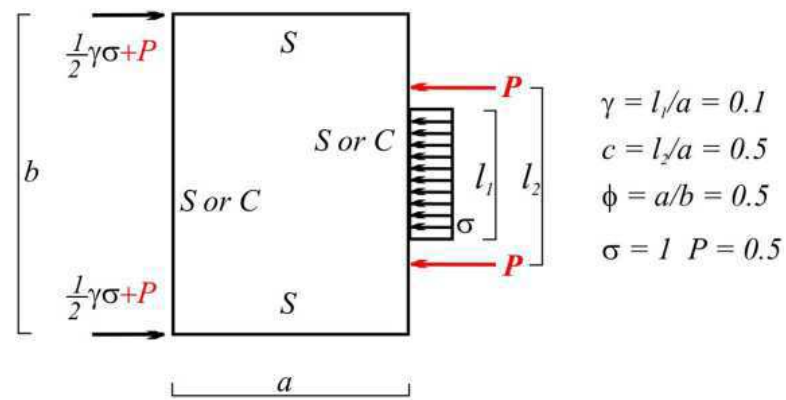

Overlapping of analytical and numerical buckling shapes SSSS

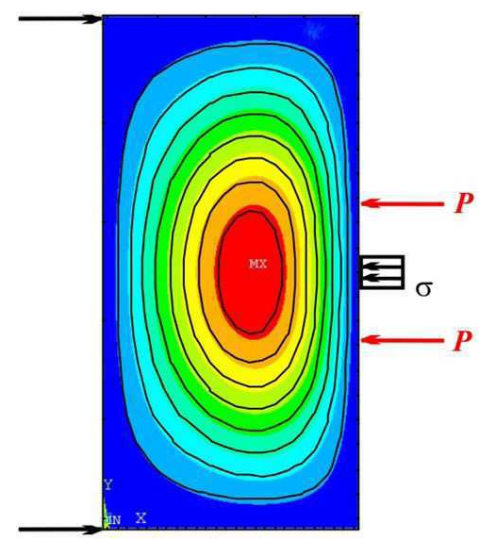

CSCS

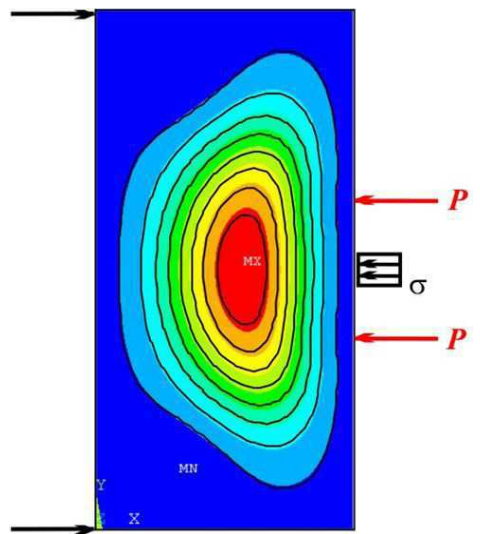

Buckling load

Analytical solution

$$
\begin{gathered}
K=5.7672 \quad K= \\
\text { discrepancy } 0.02 \%
\end{gathered}
$$

Analytical solution

ANSYS

$K=16.3867$

$\mathrm{K}=16.3857$ 


\section{EXAMPLES AND RESULTS}

Examples proposed in this article are used not only as a way to prove precision of presented analytical approach but also to control behavior of the basic load types DEA and DEB in the cases of plates with different boundary conditions. Although, DEA and DEB loads are only two of eight fundamental cases (Figure 2), they are essential in the process of external load simulation. Namely, most of the real-life construction loads can be exactly described by appropriate superposition of several basic solutions, but patch compression and/or concentrated force (DEA and DEB) are almost inevitable part of each combination.
Chosen numerical examples are rather demanding and complex load cases shown in Figure 1. Two specific plate categories concerning boundary conditions (SSSS and CSCS), with plate aspect ratios $\phi=a / b=0.5$ and 1 , under combination of patch loading with load length ratio $y=0.1-0.5$ $(Y=11 / a$, intensity $\sigma=1)$ and wheel loads $c=0.1$ 0.5 ( $c=12 / a$, intensity $P=0.1-0.5$ ) were tested. Only few, chosen results are presented in Table 3 due to huge number of available data formed by combinations of various positions, intensities and characters of loads, as well as dimensions and boundary conditions of plates. Accuracy is guaranteed by quality of basic solutions.

Table 3: Buckling load for two plate types under various cases of patch and wheel load

\begin{tabular}{|c|c|c|c|c|c|c|c|c|c|c|c|}
\hline \multirow{2}{*}{\multicolumn{2}{|c|}{$\begin{array}{c}\text { Results } \\
\left(K=\sigma \mathrm{tb}^{2} / \Pi^{2} \mathrm{D}\right)\end{array}$}} & \multicolumn{10}{|c|}{ Analytical solution $\Phi=0.5$} \\
\hline & & \multicolumn{5}{|c|}{ Plate SSSS } & \multicolumn{5}{|c|}{ Plate CSCS } \\
\hline Y & $\mathrm{P}$ & $c=0.1$ & $c=0.2$ & $c=0.3$ & $c=0.4$ & $c=0.5$ & $c=0.1$ & $c=0.2$ & $c=0.3$ & $c=0.4$ & $c=0.5$ \\
\hline \multirow{5}{*}{$\begin{array}{l}\check{0} \\
\text { II } \\
>\end{array}$} & 0.0 & 87.4985 & 87.4985 & 87.4985 & 87.4985 & 87.4985 & 254.9632 & 254.9632 & 254.9632 & 254.9632 & 254.9632 \\
\hline & 0.1 & 19.4285 & 20.0328 & 20.9511 & 22.1246 & 23.5053 & 51.5589 & 53.7950 & 57.1118 & 61.4004 & 66.4303 \\
\hline & 0.3 & 7.4809 & 7.7479 & 8.1521 & 8.6661 & 9.2651 & 19.8631 & 20.8441 & 22.2969 & 24.1716 & 26.3092 \\
\hline & 0.5 & 4.6323 & 4.8026 & 5.0608 & 5.3873 & 5.7672 & 12.3010 & 12.9258 & 13.8504 & 15.0416 & 16.3867 \\
\hline & 1.0 & 2.3731 & 2.4624 & 2.5974 & 2.7685 & 2.9666 & 6.3024 & 6.6295 & 7.1132 & 7.7354 & 8.4319 \\
\hline \multirow{5}{*}{$\begin{array}{l}\text { N } \\
0 \\
\text { II } \\
>\end{array}$} & 0.0 & 44.3406 & 44.3406 & 44.3406 & 44.3406 & 44.3406 & 130.0145 & 130.0145 & 130.0145 & 130.0145 & 130.0145 \\
\hline & 0.1 & 16.2432 & 16.6624 & 17.3026 & 18.1235 & 19.0935 & 43.1666 & 44.7151 & 47.0287 & 50.0249 & 53.5787 \\
\hline & 0.3 & 6.9557 & 7.1859 & 7.5353 & 7.9811 & 8.5035 & 18.4789 & 19.3245 & 20.5821 & 22.2117 & 24.1015 \\
\hline & 0.5 & 4.4253 & 4.5806 & 4.8157 & 5.1150 & 5.4642 & 11.7557 & 12.3249 & 13.1698 & 14.2620 & 15.5119 \\
\hline & 1.0 & 2.3176 & 2.4027 & 2.5314 & 2.6949 & 2.8847 & 6.1561 & 6.4678 & 6.9295 & 7.5247 & 8.1965 \\
\hline \multirow{5}{*}{$\begin{array}{l}m \\
0 \\
11\end{array}$} & 0.0 & 30.1776 & 30.1776 & 30.1776 & 30.1776 & 30.1776 & 89.1887 & 89.1887 & 89.1887 & 89.1887 & 89.1887 \\
\hline & 0.1 & 14.0546 & 14.3605 & 14.8299 & 15.4332 & 16.1468 & 37.4865 & 38.6104 & 40.3051 & 42.5073 & 45.1239 \\
\hline & 0.3 & 6.5241 & 6.7210 & 7.0253 & 7.4144 & 7.8719 & 17.3564 & 18.0873 & 19.1821 & 20.6058 & 22.2726 \\
\hline & 0.5 & 4.2454 & 4.3871 & 4.6023 & 4.8765 & 5.1975 & 11.2905 & 11.8096 & 12.5824 & 13.5845 & 14.7415 \\
\hline & 1.0 & 2.2673 & 2.3484 & 2.4712 & 2.6273 & 2.8090 & 6.0262 & 6.3230 & 6.7634 & 7.3324 & 7.9786 \\
\hline \multirow{5}{*}{$\begin{array}{l}+ \\
0 \\
11 \\
>\end{array}$} & 0.0 & 23.2385 & 23.2385 & 23.2385 & 23.2385 & 23.2385 & 69.3095 & 69.3095 & 69.3095 & 69.3095 & 69.3095 \\
\hline & 0.1 & 12.4882 & 12.7206 & 13.0753 & 13.5391 & 14.0846 & 33.4875 & 34.3413 & 35.6359 & 37.3210 & 39.3245 \\
\hline & 0.3 & 6.1635 & 6.3386 & 6.6054 & 6.9471 & 7.3496 & 16.4495 & 17.0917 & 18.0526 & 19.3029 & 20.7734 \\
\hline & 0.5 & 4.0910 & 4.2209 & 4.4182 & 4.6700 & 4.9652 & 10.9009 & 11.3768 & 12.0859 & 13.0060 & 14.0735 \\
\hline & 1.0 & 2.2225 & 2.2999 & 2.4171 & 2.5662 & 2.7399 & 5.9135 & 6.1968 & 6.6172 & 7.1606 & 7.7801 \\
\hline \multirow{5}{*}{$\begin{array}{l}0 \\
0 \\
11 \\
>\end{array}$} & 0.0 & 19.1729 & 19.1729 & 19.1729 & 19.1729 & 19.1729 & 57.7698 & 57.7698 & 57.7698 & 57.7698 & 57.7698 \\
\hline & 0.1 & 11.3311 & 11.5135 & 11.7950 & 12.1581 & 12.5883 & 30.5891 & 31.2662 & 32.2923 & 33.6250 & 35.2091 \\
\hline & 0.3 & 5.8699 & 6.0246 & 6.2606 & 6.5627 & 6.9187 & 15.7255 & 16.2968 & 17.1498 & 18.2557 & 19.5552 \\
\hline & 0.5 & 3.9599 & 4.0795 & 4.2611 & 4.4928 & 4.7647 & 10.5794 & 11.0195 & 11.6740 & 12.5208 & 13.5033 \\
\hline & 1.0 & 2.1834 & 2.2573 & 2.3693 & 2.5117 & 2.6777 & 5.5180 & 6.0894 & 6.4917 & 7.0108 & 7.6028 \\
\hline
\end{tabular}




\begin{tabular}{|c|c|c|c|c|c|c|c|c|c|c|c|}
\hline \multirow{2}{*}{\multicolumn{2}{|c|}{$\begin{array}{c}\text { Results } \\
\left(K=\sigma \mathrm{tb}^{2} / \Pi^{2} \mathrm{D}\right)\end{array}$}} & \multicolumn{10}{|c|}{ Analytical solution $\Phi=0.5$} \\
\hline & & \multicolumn{5}{|c|}{ Plate SSSS } & \multicolumn{5}{|c|}{ Plate CSCS } \\
\hline Y & $\mathrm{P}$ & $c=0.1$ & $c=0.2$ & $c=0.3$ & $c=0.4$ & $c=0.5$ & $c=0.1$ & $c=0.2$ & $c=0.3$ & $c=0.4$ & $c=0.5$ \\
\hline \multirow{5}{*}{$\begin{array}{l}\check{0} \\
\text { II } \\
>\end{array}$} & 0.0 & 29.4925 & 29.4925 & 29.4925 & 29.4925 & 29.4925 & 57.3550 & 57.3550 & 57.3550 & 57.3550 & 57.3550 \\
\hline & 0.1 & 9.9230 & 10.3208 & 10.9536 & 11.8073 & 12.8608 & 19.2635 & 19.8512 & 20.7400 & 21.8947 & 23.2558 \\
\hline & 0.3 & 4.2640 & 4.4839 & 4.8395 & 5.3343 & 5.9727 & 8.2731 & 8.5933 & 9.0835 & 9.7365 & 10.5283 \\
\hline & 0.5 & 2.7154 & 2.8640 & 3.2052 & 3.4437 & 3.8855 & 5.2677 & 5.4831 & 5.8139 & 6.2574 & 6.7988 \\
\hline & 1.0 & 1.4232 & 1.5048 & 1.6377 & 1.8256 & 2.0731 & 2.7606 & 2.8785 & 3.0599 & 3.3045 & 3.6047 \\
\hline \multirow{5}{*}{$\begin{array}{l}\text { Nִ } \\
\text { II } \\
>\end{array}$} & 0.0 & 15.0502 & 15.0502 & 15.0502 & 15.0502 & 15.0502 & 29.1458 & 29.1458 & 29.1458 & 29.1458 & 29.1458 \\
\hline & 0.1 & 7.5009 & 7.7248 & 8.0773 & 8.5414 & 9.0934 & 14.5368 & 14.8656 & 15.3647 & 16.0028 & 16.7370 \\
\hline & 0.3 & 3.7444 & 3.0128 & 4.1831 & 4.5535 & 5.0203 & 7.2593 & 7.5042 & 2.9104 & 8.3741 & 8.9658 \\
\hline & 0.5 & 2.4949 & 2.6198 & 2.8214 & 3.1013 & 3.4608 & 4.8375 & 5.0185 & 5.2964 & 5.6665 & 6.1141 \\
\hline & 1.0 & 1.3602 & 1.4345 & 1.5553 & 1.7249 & 1.9463 & 2.6377 & 2.7451 & 7.8793 & 3.1232 & 3.4036 \\
\hline \multirow{5}{*}{$\begin{array}{l}n \\
0 \\
11 \\
>\end{array}$} & 0.0 & 10.3563 & 10.3563 & 10.3563 & 10.3563 & 10.3563 & 19.9023 & 19.9023 & 19.9023 & 19.9023 & 19.9023 \\
\hline & 0.1 & 6.1201 & 6.2649 & 6.4924 & 6.7887 & 7.1350 & 11.8055 & 12.0140 & 12.3336 & 12.7420 & 13.2074 \\
\hline & 0.3 & 3.3656 & 3.4994 & 3.7134 & 4.0037 & 4.3638 & 6.5081 & 6.7006 & 6.9970 & 7.3867 & 7.8486 \\
\hline & 0.5 & 2.3209 & 2.4277 & 2.5997 & 2.8365 & 3.1369 & 4.4921 & 4.6458 & 4.8825 & 5.1970 & 5.5749 \\
\hline & 1.0 & 1.3068 & 1.3750 & 1.4855 & 1.6399 & 1.8400 & 2.5315 & 2.6297 & 2.7809 & 2.9837 & 3.2304 \\
\hline \multirow{5}{*}{$\begin{array}{l}ナ \\
0 \\
\text { II } \\
>\end{array}$} & 0.0 & 8.0916 & 8.0916 & 8.0916 & 8.0916 & 8.0916 & 15.3852 & 15.3852 & 15.3852 & 15.3852 & 15.3852 \\
\hline & 0.1 & 5.2544 & 5.3575 & 5.5194 & 5.7295 & 5.9732 & 10.0596 & 10.2046 & 10.4284 & 10.7153 & 11.0418 \\
\hline & 0.3 & 3.0869 & 3.1969 & 3.3725 & 3.6092 & 3.8997 & 5.9413 & 6.0975 & 6.3386 & 6.6553 & 7.0290 \\
\hline & 0.5 & 2.1851 & 2.2781 & 2.4277 & 2.6326 & 2.8901 & 4.1249 & 4.3476 & 4.5524 & 4.8239 & 5.1490 \\
\hline & 1.0 & 1.2627 & 1.3257 & 1.4277 & 1.5696 & 1.7525 & 2.4412 & 2.5314 & 2.6705 & 2.8568 & 3.0829 \\
\hline \multirow{5}{*}{$\begin{array}{l}0 \\
0 \\
11 \\
>\end{array}$} & 0.0 & 6.7933 & 6.7933 & 6.7933 & 6.7933 & 6.7933 & 12.7487 & 12.7487 & 12.7487 & 12.7487 & 12.7487 \\
\hline & 0.1 & 4.6781 & 4.7570 & 4.8809 & 5.0414 & 5.2269 & 8.8672 & 8.9757 & 9.1435 & 9.3588 & 9.6039 \\
\hline & 0.3 & 2.8799 & 2.9734 & 3.1223 & 3.3220 & 3.5652 & 5.5063 & 5.6371 & 5.8391 & 6.1035 & 6.4147 \\
\hline & 0.5 & 2.0797 & 2.1624 & 2.2952 & 2.4761 & 2.8019 & 3.9918 & 4.1085 & 4.2887 & 4.5269 & 4.8111 \\
\hline & 1.0 & 1.2269 & 1.2857 & 1.3807 & 1.5125 & 1.6814 & 2.3649 & 2.4485 & 2.5775 & 2.7498 & 2.9585 \\
\hline
\end{tabular}

In case of simply supported plate (Table 3 ), extremely good behavior of analytical model is confirmed. Maximal discrepancy from numerical (FEM) solution is less than $0.3 \%$.

On the other side, load action over clamped edge (Table 3), leads to slightly higher differences ( $\max$ $0.5 \%$ ), but still proving good capability of deflection functions to adequately simulate buckling shapes even in these specific plate types.

All of these examples are highly demanding in each aspect of presented analytical approach. Stress functions have to describe precisely very complex stress distribution within plate under patch load and system of concentrated forces, while deflection functions have to be capable of providing ideal buckling shape for all load combinations (Table 2).

Hence, it has been proved that adopted deflection functions and defined stress functions, for the analyzed cases of plates with mixed boundary conditions, subjected to patch and wheel loads (DEA and DEB) are capable to produce highly accurate solutions.

Finally, it may be concluded that shown procedure presents rare analytical approach to stability problems of plates with different boundary conditions which satisfies very demanding criteria of accuracy and applicability in rather complex cases of external load.

\section{REFERENCES}

1) Baker G., Pavlović M. N., Tahan N. (1993): "An exact solution to the two-dimensional elasticity problem with rectangular boundaries under arbitrary edge forces", Phil. Trans. R. Soc. London, A 393, pp. 307-336

2) Liu Y. G. (2006): "Buckling of Plates under Non-Uniform Stresses, with Particular Emphasis on Shear", Ph. D Thesis, Imperial College, London

3) Mathieu E. (1890): "Theorie de l'elasticite des corps solides", Seconde partie. Gauthier Villars, Paris 
4) Mijušković O. (2008): "Analiza stabilnosti pravougaonih ploča korišćenjem tačne funkcije napona", Doktorska disertacija, Građevinski fakultet Univerziteta u Beogradu, Beograd

5) Mijušković O., Ćorić B. (2013): "Patch loading - analytical approach to critical load determination", original scientific paper, Građevinar, Journal of the Croatian Association of Civil Engineers, 65(1), pp. 1-10

6) Mijušković O., Ćorić B., Šćepanović B. (2014): "Exact stress functions implementation in stability analysis of plates with different boundary conditions under uniaxial and biaxial compression", Thin-Walled Structures, 80, pp. 192-206
7) Mijušković O., Ćorić B., Šćepanović B. (2015): "Accurate buckling loads of plates with different boundary conditions under arbitrary edge compression", International Journal of Mechanical Sciences, 101-102, pp.309-323

8) Mijušković O., Ćorić B., Šćepanović B.,Žugić Lj. (2016): " Analytical model for buckling analysis of the plates under patch and concentrated loads ", Thin-Walled Structures, 101, pp.26-42

Paper sent to revision: 05.02.2016.

Paper ready for publication: 15.03.2016. 


\section{KOMBINACIJA FLASTERA I TOČKA OPTEREĆENJA - ANALITIČKI PRISTUP KOPČANJU PLOČA}

Olga Mijušković, Univerzitet Crne Gore, Građevinski fakultet, Podgorica, Crna Gora Branislav Ćorić, Univerzitet u Beogradu, Građevinski fakultet, Beograd, Srbija Biljana Ščepanović, Univerzitet Crne Gore, Građevinski fakultet, Podgorica, Crna Gora

Protekle studije o stabilnosti pravougaone ploče pod uticajem promenljivih opterećenja su zasnovane na pretpostavkama simplificiranih stres distribucija, u kojima je pitanje tačnost rezultata dobijenih na taj način. Postupak primene tačno stresa funkcije u problemu elastične stabilnosti ploče sa različitim graničnim uslovima pod efektima flastera i točka opterećenja je prikazan u ovom radu. Mathieu (1890) dobio je tačno rešenje za ravan naprezanja za pravougaoni element za pojedine vrste promenljivih pritisak na granicama. Pekar al (1993), nakon Mathieu je rezultate, analizirali opšti problem pravougaonog ploče opterećene od potpuno proizvoljnim distribucija (normalna i / ili makazama) naglašenim duž ivica ploče.

Analitički pristup se koristi za određivanje kritičnog opterećenja zasnovan na dobro poznatom energetskom tehnikom Ritz. Energija naprezanja zahvaljujući savijanju ploče definisan je na tradicionalan način. S druge strane, distribucija tačnog naprezanja Mathieu teorije elastičnosti uvodi kroz potencijalne energije ploče povezanog sa obavljenog posla eksternim opterećenjem.

Rezultati za dobijeno kritično opterećenje predstavljeni analitičkim pristupom potvrđeno numeričkim konačnim elementima (FE) radi.

Ključne reči: Elastična stabilnost ploča, Egzaktna funkcija naprezanja, Flaster i točak opterećenja 